\title{
MENINGKATKAN KEMAMPUAN BERPIKIR KRITIS MELALUI ALAT PERAGA PILOGMA PADA MATERI LOGIKA MATEMATIKA
}

\author{
Lia Tuti Alawiah', Desi Rahmatina², Febrian $^{3}$ \\ ${ }^{1}$ liatutialawiah@gmail.com \\ 1,2,3Universitas Maritim Raja Ali Haji \\ 2018
}

\begin{abstract}
Abstrak
Tujuan penelitian ini adalah untuk mengetahui bagaimana peningkatan kemampuan berpikir kritis siswa dengan menggunakan alat peraga Pilogma pada materi nilai kebenaran pernyataan majemuk Logika Matematika. Penelitian ini merupakan Penelitian Tindakan Kelas (PTK). Penelitian jenis kualitatif ini dilaksanakan dalam 2 siklus dan setiap siklus diadakan 2 kali pertemuan. Peneliti menggunakan teknik observasi, dokumentasi, wawancara, dan tes untuk memperoleh data. Teknik analisis data melalui tahap reduksi data, penyajian data dan penarikan kesimpulan dan verifikasi serta triangulasi data. Subjek penelitiannya adalah kelas X SMA Muhammadiyah Tanjungpinang. Objek penelitian yaitu meningkatkan kemampuan berpikir kritis siswa yang dilihat melalui hasil tes setiap akhir siklus I dan II serta hasil observasi, dokumentasi dan wawancara. Hasil penelitian menunjukkan bahwa kemampuan berpikir kritis siswa dapat ditingkatkan melalui penggunaan alat peraga Pilogma dalam pembelajaran materi Logika Matematika.
\end{abstract}

Kata kunci: logika matematika, kemampuan berpikir kritis, alat peraga Pilogma

\begin{abstract}
The purpose of this study is to find out how to improve students' critical thinking skills by using props Pilogma on the material of truth value of compound logic mathematical statements. This research is a Classroom Action Research. This qualitative research was conducted by using 2 cycles and each cycle contained 2 class meetings. Researchers used observation techniques, documentation, interviews, and tests to obtain data. Data analysis techniques through the data reduction phase, data presentation and conclusion drawing and verification and triangulation of data. The subject of this research is class $X$ of SMA Muhammadiyah Tanjungpinang. The object of research is to improve students' critical thinking ability which can be seen through test result at the end of cycle I and II and observation, documentation and interview. The results showed that students' critical thinking ability can be improved through the use of props Pilogma in learning Mathematics Logic material.
\end{abstract}

Keywords: mathematical logic, critical thinking skills, props Pilogma 
JURNAL GANTANG. Maret 2018; III(1): 55 - 61

p-ISSN. 2503-0671

e-ISSN. 2548-5547

\section{Pendahuluan}

Matematika merupakan ilmu universal yang mendasari perkembangan teknologi modern, mempunyai peran penting dalam berbagai disiplin dan memajukan daya pikir manusia (Ibrahim \& Suparni, 2013). Perkembangan teknologi informasi dan komunikasi tersebut, dilandasi oleh perkembangan di bidang ilmu matematika. Untuk dapat menciptakan teknologi-teknologi baru tentu diperlukan penguasaan matematika yang kuat sejak dini. Hal ini menunjukkan peranan matematika dalam kehidupan sangat utama dan penting. Dengan demikian, matematika dijadikan sebagai salah satu mata pelajaran yang wajib diajarkan mulai dari pendidikan dasar, pendidikan menengah sampai perguruan tinggi.

Salah satu kemampuan berpikir dalam pembelajaran matematika ialah kemampuan berpikir kritis. Siswa menggunakan kemampuan berpikirnya dalam pembelajaran berkenaan dengan proses menganalisa, menentukan kemungkinan-kemungkinan jawaban/solusi dan memberikan kesimpulan sebagai keputusan akhir dari penyelesaian suatu masalah. Proses meningkatkan dan mengembangkan kemampuan berpikir tersebut, diperlukan upaya guru dalam menciptakan strategi pembelajaran yang memfasilitasi siswa agar mau memikirkan apa yang sedang dipelajari lebih jauh.

Berdasarkan observasi peneliti pada kegiatan Praktik Pengalaman Lapangan (PPL) semester genap tahun pelajaran 2016/2017 di kelas X SMA Muhammadiyah Tanjungpinang selama kurang lebih 6 bulan, dalam pembelajaran beberapa siswa masih terlihat kebingungan dan sulit dalam memahami dan mendeskripsikan ulang suatu materi yang sedang dipelajari. Selain itu, ditemukan siswa yang masih enggan untuk bertanya dan mengikuti proses pembelajaran di kelas matematika. Selain rendahnya pemahaman konsep, siswa masih kesulitan dalam menganalisa dan memberikan kesimpulan terhadap materi yang sedang dipelajari. Bahkan, terkadang siswa bingung dan ragu-ragu ketika akan menyampaikan ide/pendapat dalam diskusi kelas. Kurangnya kepercayaan diri siswa menyebabkan kemampuan berpikir tidak digunakan dengan optimal.

Salah satu penyebabnya ialah dalam kegiatan pembelajaran guru terlalu mengambil peranan yang melebihi tugasnya sebagai seorang fasilitator. Guru belum menerapkan proses pembelajaran yang dapat menciptakan terjadinya interaksi dan komunikasi antara guru dan siswa. Sehingga siswa dalam pembelajaran hanya pasif dan tidak mau memikirkan lebih jauh mengenai materi yang sedang diajarkan. Situasi tersebut menyebabkan kurangnya keaktifan siswa sebagai subjek yang ingin dan mempunyai tujuan belajar.

Salah satu materi yang sifatnya abstrak yaitu logika matematika. Logika matematika merupakan ilmu yang mempelajari kaidah dalam pengambilan keputusan. Dalam pembelajaran, diperlukan pemahaman siswa dalam menentukan nilai kebenaran dan memecahkan permasalahan terkait pernyataan majemuk diantaranya yaitu konjungsi dan disjungsi. Dengan mempelajari materi konjungsi dan disjungsi akan muncul ide-ide abstrak yang akan dikongkritkan dengan alat peraga.

Alat peraga yang dapat digunakan untuk mengajarkan materi menentukan nilai kebenaran pernyataan majemuk yaitu Pipa Logika Matematika (Pilogma). Alat peraga Pilogma sebagai suatu media pembelajaran yang digunakan dengan tujuan memberikan kesempatan siswa untuk meningkatkan pemahaman konsep dan kemampuan berpikir kritis. Penggunaan alat peraga dilakukan dalam beberapa pertemuan pembelajaran. Hal ini bertujuan untuk mengetahui proses peningkatan pemahaman konsep dan kemampuan berpikir kritis dari tindakan yang diberikan dalam kelas tersebut. Oleh karena itu, pemakaian alat peraga dalam pembelajaran materi tersebut diharapkan dapat memudahkan siswa untuk memikirkan 
apa yang sedang dipelajari. Siswa dapat melihat, mengamati dan menggunakan alat peraga tersebut dan mengkaitkannya dengan materi yang sedang dipelajari, bukan dengan menghapal suatu fakta/konsep materi tertentu saja. Selain itu, siswa dapat mengembangkan kemampuan berpikir kritis.

Menurut Ennis dalam Sabandar (2013) berpikir kritis adalah suatu proses berpikir yang terjadi pada seseorang dan bertujuan untuk membuat keputusan-keputusan yang masuk akal mengenai sesuatu yang dapat ia yakini kebenarannya serta yang akan dilakukan nanti. Menurut Reber (Syah, 2011: 118) dalam hal berpikir kritis, siswa dituntut menggunakan strategi kognitif tertentu yang tepat untuk menguji keandalan gagasan pemecahan masalah dan mengatasi kesalahan atau kekurangan. Dari pengertian diatas, dapat disimpulkan bahwa berpikir kritis ialah kemampuan siswa dalam menganalisa dan memberikan kesimpulan/solusi terhadap permasalahan yang ditemukan. Pada saat proses berpikir siswa mempertimbangkan dan mengevaluasi informasi yang pada akhirnya memungkinkan siswa secara aktif dan yakin membuat keputusan.

Selanjutnya, Ennis (2011) dalam Ika Rahmawati (2016) mengidentifikasi 12 indikator berpikir kritis yang dikelompokkan dalam 5 besar aktivitas sebagai berikut:

a. Memberikan penjelasan sederhana, yang berisi: memfokuskan pertanyaan; menganalisis pertanyaan dan bertanya; serta menjawab pertanyaan tentang suatu penjelasan atau pernyataan.

b. Membangun keterampilan dasar, yang terdiri atas mempertimbangkan apakah sumber dapat dipercaya atau tidak dan mengamati serta mempertimbangkan suatu laporan hasil observasi.

c. Menyimpulkan, yang terdiri atas kegiatan mendeduksi atau mempertimbangkan hasil deduksi, menginduksi atau mempertimbangkan hasil induksi dan membuat serta menentukan nilai pertimbangan.

d. Memberikan penjelasan lanjut, yang terdiri atas mengidentifikasi istilah-istilah dan definisi pertimbangan dan juga dimensi serta mengidentifikasi asumsi.

e. Mengatur strategi dan taktik yang terdiri atas menentukan tindakan dan berinteraksi dengan orang lain.

Indikator-indikator tersebut dalam prakteknya dapat bersatu padu membentuk sebuah kegiatan atau terpisah-pisah hanya beberapa indikator saja.

Berdasarkan uraian indikator-indikator berpikir kritis diatas, peneliti memilih beberapa indikator saja. Hal ini atas pertimbangan peneliti dengan melihat keefektifan penggunaan alat peraga Pilogma. Dengan demikian, maka aspek kemampuan berpikir kritis yang digunakan dalam penelitian ini sebagai berikut:

1) Kemampuan menganalisa masalah

Indikator terlihat dan diteliti ketika siswa mengerjakan soal dalam Lembar Aktifitas Siswa (LAS).

2) Kemampuan berpikir terbuka (mencari alternatif)

Indikator terlihat dan diteliti ketika siswa menggunakan alat peraga Pilogma dan mengerjakan soal dalam Lembar Aktifitas Siswa (LAS).

3) Kemampuan membuat kesimpulan Indikator terlihat dan diteliti ketika siswa mengerjakan soal dalam Lembar Aktifitas Siswa (LAS).

\section{Metode Penelitian}

Metode yang digunakan dalam penelitian ini yaitu Penelitian Tindakan Kelas (PTK). Model penelitian tindakan ialah model spiral yang dikembangkan oleh Kemmis dan $\mathrm{Mc}$ Taggart. Penelitian dilaksanakan dalam 2 siklus. Setiap siklus meliputi tahap perencanaan, pelaksanaan/tindakan, observasi dan refleksi. Penelitian dilaksanakan dengan tujuan mendeskripsikan peningkatkan kemampuan berpikir kritis siswa melalui penggunaan alat peraga Pilogma di kelas X SMA Muhammadiyah Tanjungpinang. Kemampuan berpikir kritis siswa dikatakan mengalami peningkatan apabila persentase rata-rata skor tes minimal $75 \%$ atau dalam kategori tinggi dan seluruh siswa 


\section{JURNAL GANTANG. Maret 2018; III(1): 55 - 61 \\ p-ISSN. 2503-0671 \\ e-ISSN. 2548-5547}

mencapai nilai tuntas sesuai Kriteria Ketuntasan Minimal (KKM) atau $\geq 75$.

Teknik pengumpulan data dalam penelitian ini antara lain observasi, tes, wawancara, dokumentasi dan catatan lapangan. Observasi dilakukan untuk melihat keterlaksanaan pembelajaran menggunakan alat peraga Pilogma. Observasi dilakukan oleh peneliti dan guru sebagai observer 2. Selain itu, catatan lapangan dan dokumentasi digunakan untuk melihat kegiatan yang terjadi selama pembelajaran dan memperkuat data. Tes diberikan untuk mengetahui dan mengukur peningkatan kemampuan berpikir kritis siswa setelah pembelajaran menggunakan alat peraga Pilogma. Tes berupa soal uraian yang disusun berdasarkan indikator kemampuan berpikir kritis yang akan diteliti. Setelah diperoleh hasil tes dan ditentukan skor rata-ratanya, kemudian skor ratarata tersebut dianalisis dan dikualifikasi berdasarkan kriteria penskoran kemampuan berpikir kritis siswa yaitu sebagai berikut.

Tabel 1. Kualifikasi Hasil Persentase Skor Tes Kemampuan Berpikir Kritis Siswa

\begin{tabular}{|c|c|}
\hline Skor & Kriteria \\
\hline $81 \%<\bar{x} \leq 100 \%$ & Sangat Tinggi \\
\hline $61 \%<\bar{x} \leq 80 \%$ & Tinggi \\
\hline $41 \%<\bar{x} \leq 60 \%$ & Sedang \\
\hline $21 \%<\bar{x} \leq 40 \%$ & Rendah \\
\hline $0 \%<\bar{x} \leq 20 \%$ & Sangat Rendah \\
\hline
\end{tabular}

(Sumber: Arikunto dan Abdul (2014: 35)

Keterangan:

$\bar{x}=$ rata-rata nilai tes kemampuan berpikir kritis siswa (dalam \%).

Kemudian, peneliti melakukan wawancara dengan tujuan memperoleh informasi tambahan mengenai respon dan kesulitan yang dialami siswa selama pembelajaran menggunakan alat peraga Pilogma. Data hasil observasi, wawancara dan dokumentasi dianalisis dengan mereduksi data, menyajikan data dan membuat kesimpulan. Selanjutnya, untuk mengetahui data yang telah diperoleh dari observasi, wawancara dan dokumentasi apakah menghasilkan data yang sama dilakukan triangulasi data.

\section{Hasil dan Pembahasan}

Penelitian dilaksanakan mulai tanggal 22 Mei sampai 10 Juni 2017 di kelas X SMA Muhammadiyah Tanjungpinang. Penelitian dilaksanakan dalam 2 siklus. Setiap siklus diadakan dua kali pertemuan dengan materi ajar yang berbeda. Berdasarkan keefektifan alat peraga Pilogma, maka materi Logika Matematika yang diajarkan yaitu konjungsi, disjungsi, negasi konjungsi dan disjungsi serta eksplorasi alat peraga Pilogma.

$$
\text { Penggunaan Pilogma dalam }
$$
pembelajaran dapat mengembangkan kemampuan berpikir kritis siswa pada kegiatan eksplorasi alat peraga. Kegiatan eksplorasi pada siklus II yaitu siswa diberikan beberapa kasus Pilogma bola sampai wadah dan tidak sampai wadah. Setelah menganalisa masalah, siswa mengingat kembali konsep konjungsi dan disjungsi. Dengan memahami konsep bahwa pipa konjungsi seperti susunan rangkaian seri dan disjungsi seperti rangkaian paralel, siswa dapat menentukan kemungkinan pernyataan tunggal dan nilai kebenarannya. Kegiatan tersebut menuntut siswa berpikir kritis dalam menentukan berbagai kemungkinan kalimat majemuk atau gabungan kalimat majemuk yang terdiri dari dua atau lebih pernyataan tunggal serta nilai kebenarannya sesuai gambar/kasus yang diberikan. Selanjutnya, pada kegiatan diskusi, rata - rata siswa aktif menyampaikan pendapat secara bergantian.

Guru meminta siswa menuliskan jawabannya dan mendemonstrasikan Pilogma di depan kelas. Kegiatan tersebut meningkatkan rasa percaya diri dan tanggung jawab siswa. Dengan demikian, pembelajaran menggunakan alat peraga dapat menciptakan suasana belajar yang luwes, siswa aktif mengemukakan pendapat dan menemukan konsep materi dengan mandiri sehingga kualitas pembelajaran menjadi lebih baik. Hal tersebut sesuai dengan pernyataan Sabri dalam Musfiqon (2012: 9) bahwa kualitas 
pengajaran menjadi lebih baik yaitu dengan adanya fasilitas dan sumber belajar berupa alat peraga.

Setelah dilaksanakan pembelajaran, diadakan tes untuk setiap siklus. Selanjutnya, hasil tes untuk masing-masing indikator kemampuan berpikir kritis disajikan pada tabel berikut ini.

Tabel 2. Hasil Tes Kemampuan Berpikir Kritis Siklus II

\begin{tabular}{|l|c|c|}
\hline \multicolumn{1}{|c|}{ Indikator } & $\begin{array}{c}\text { Persentase } \\
\text { siklus I }\end{array}$ & $\begin{array}{c}\text { Persentase } \\
\text { siklus II }\end{array}$ \\
\hline $\begin{array}{l}\text { Kemampuan } \\
\text { menganalisis } \\
\text { masalah }\end{array}$ & $67,85 \%$ & $85,71 \%$ \\
\hline $\begin{array}{l}\text { Kemampuan } \\
\text { berpikir } \\
\text { terbuka/mencari } \\
\text { alternatif } \\
\text { pemecahan } \\
\text { masalah }\end{array}$ & $71,42 \%$ & $85,71 \%$ \\
\hline $\begin{array}{l}\text { Kemampuan } \\
\text { membuat } \\
\text { kesimpulan }\end{array}$ & $71,42 \%$ & $85,71 \%$ \\
\hline Rata - rata & $\mathbf{6 9 , 8 4 \%}$ & $\mathbf{8 5 , 7 1 \%}$ \\
\hline
\end{tabular}

Pada siklus I, siswa menganalisis masalah kemudian melengkapi tabel kebenaran untuk setiap pernyataan tunggal dan pernyataan majemuk dengan beberapa informasi yang ditemukan dalam soal. Tes siklus memperoleh persentase sebesar $67,85 \%$. Berdasarkan hasil tes, masih ada beberapa siswa yang belum tepat melengkapi tabel kebenaran, pernyataan tunggal dan pernyataan majemuk. Peningkatan terjadi pada siklus II yaitu sebesar $85,71 \%$. Beberapa siswa sudah tepat menuliskan nilai kebenaran pernyataan tunggal dan pernyataan majemuk.

Indikator berpikir kritis yang kedua yaitu kemampuan siswa mencari alternatif pemecahan masalah. Berdasarkan hasil tes, siswa tidak menuliskan semua kemungkinan nilai kebenaran untuk setiap pernyataan tunggal dan pernyataan majemuk dengan persentase $71,42 \%$. Selanjutnya mengalami peningkatan pada siklus II yaitu siswa membuktikan dua pernyataan majemuk yang ekuivalensi dengan tabel kebenaran dengan persentase $85,71 \%$.
Indikator berpikir kritis selanjutnya yaitu kemampuan siswa dalam membuktikan kesimpulan mengalami peningkatan dari 71, $42 \%$ menjadi $85,71 \%$. Siswa sudah tepat dalam menentukan kesimpulan nilai kebenaran suatu pernyataan majemuk setelah melengkapi tabel kebenaran. Sedangkan pada siklus II, beberapa siswa tepat membuktikan dan menyatakan bahwa dua pernyataan majemuk ekuivalen dengan tabel kebenaran.

Selanjutnya setelah diadakan tes siklus II, semua siswa telah mencapai ketuntasan belajar sesuai nilai Kriteria Ketuntasan Minimal (KKM) atau nilai $\geq 75$. Setelah dilakukan analisis, hasil tes dari kedua siklus tersebut menunjukkan bahwa pembelajaran menggunakan alat peraga mampu memudahkan siswa memahami materi yang diajarkan yang dilihat dari peningkatan persentase untuk setiap indikator pemahaman dan berpikir kritis. Hal ini sesuai dengan pendapat Ibrahim dan Suparni (2012: 83) yang menyatakan bahwa setiap konsep atau prinsip dapat dimengerti secara sempura jika awalnya disajikan dalam bentuk konkret.

Selanjutnya, dari hasil analisis wawancara rata-rata siswa mengatakan lebih tertarik mengikuti pembelajaran menggunakan alat peraga Pilogma. Hasil tersebut sesuai dengan pendapat dari Musfiqon (2012: 32) bahwa media pembelajaran dapat membangkitkan motivasi dan minat siswa. Selain itu, siswa dapat mengembangkan kemampuan berpikir kritisnya melalui kegiatan eksplorasi.

Dengan demikian, berdasarkan data observasi keterlaksanaan pembelajaran menggunakan Pilogma dan hasil tes menunjukkan bahwa pembelajaran logika matematika materi pernyataan majemuk konjungsi dan disjungsi serta eksplorasi menggunakan alat peraga Pilogma di kelas X SMA Muhammadiyah Tanjungpinang dapat meningkatkan kemampuan berpikir kritis siswa.

\section{Penutup}

Berdasarkan penelitian yang dilaksanakan di kelas X SMA Muhammadiyah Tanjungpinang, peneliti dapat menyimpulkan 


\section{JURNAL GANTANG. Maret 2018; III(1): 55 - 61 \\ p-ISSN. 2503-0671 \\ e-ISSN. 2548-5547}

bahwa pada kegiatan eksplorasi alat peraga yaitu siswa diminta menemukan dan menentukan beberapa kemungkinan pernyataan majemuk. Pada kegiatan tersebut siswa dihadapkan pada kondisi/kasus gambar Pilogma untuk bola sampai wadah dan tidak sampai wadah. Dengan memahami konsep bahwa pipa konjungsi seperti susunan rangkaian seri dan disjungsi seperti rangkaian paralel, pengetahuan tersebut membantu siswa dalam menentukan bentuk pernyataan majemuk yang mungkin dari gambar Pilogma yang diberikan. Kegiatan eksplorasi dapat mengembangkan kemampuan berpikir kritis siswa melalui tahap menganalisa masalah, mencoba menemukan beberapa solusi/ kemungkinan jawaban sehingga pada akhirnya dapat memberikan kesimpulan dengan tepat terhadap suatu masalah yang diberikan. Persentase untuk kemampuan berpikir kritis siswa mengalami peningkatan dari rata-rata 69 , $84 \%$ atau dalam kategori tinggi menjadi 85, $71 \%$. Dengan demikian, kemampuan berpikir kritis siswa termasuk dalam kriteria sangat tinggi. Selain itu, semua siswa kelas X SMA Muhammadiyah Tanjungpinang telah mencapai tuntas belajar sesuai KKM atau nilai $\geq 75$.

Berdasarkan hasil observasi dan wawancara terkait respon siswa selama pembelajaran matematika menggunakan alat peraga Pilogma, maka saran-saran yang dihasilkan adalah sebagai berikut:

1. Pembelajaran menggunakan alat peraga diharapkan dapat dilaksanakan untuk materi matematika lainnya yang sifatnya abstrak dan perlu dikonkretkan dengan benda nyata sehingga konsep materi mudah dipahami dan meingkatkan kemampuan berpikir kritis siswa.

2. Adanya penelitian lanjutan dan pembaharuan mengenai alat peraga Pilogma sehingga efektif digunakan untuk materi pernyataan majemuk konjungsi, disjungsi, implikasi dan biimplikasi serta pernyataan majemuk berkuantor.

3. Guru perlu menyiapkan sarana dan prasarana yang berkaitan dengan kemudahan dan keberhasilan siswa dalam mencapai tujuan belajarnya. Dengan demikian, siswa dapat mencapai ketuntasan belajar optimal.

\section{Referensi}

Arikunto, S. (2013). Dasar-dasar Evaluasi Pendidikan. Jakarta: Bumi Aksara

Arikunto, S, dkk. (2015). Penelitian Tindakan Kelas. Jakarta: Bumi Aksara.

Arikunto, S dan Jabar, A. Safruddin. (2014). Evaluasi Program Pendidikan. Jakarta: Bumi Aksara.

Arsyad, A. (2014). Media Pembelajaran. Jakarta: Raja Grafindo Persada.

Fariski, M. (2012). Efektivitas Metode Pembelajaran Improve dengan Bantuan Alat Peraga Miniatur Tandon Air terhadap Hasil Belajar Peserta Didik pada Materi Logika Matematika Semester Genap Kelas X SMA Islam Sultan Agung 1 Semarang Tahun Pelajaran 2011/2012. IAIN Walisongo. Diambil dari http://eprints.walisongo.ac.id/397/.

Fathurrohman, M. (2015). Model-Model Pembelajaran Inovatif. Yogyakarta: $\mathrm{Ar}-$ Ruzz Media

Herdian. (2010). Kemampuan Pemahaman Matematika. [Online]. Tersedia :https://herdy07.wordpress.com/2010/05/27/ kemampuan-pemahaman-matematis/.

Http://pasca.um.ac.id/wpcontent/uploads/2017/02 /Ika-Rahmawati-1111119.pdf

Ibrahim dan Suparni. (2012). Pembelajaran Matematika Teori dan Aplikasinya. Yogyakarta: SUKA-Press.

Lusi, Samuel dan Nggili, R.A. (2013). Asyiknya Penelitian Ilmiah dan Penelitian Tindakan Kelas. Yogyakarta: ANDI OFFSET.

Musfiqon. (2012). Pengembangan Media dan Sumber Pembelajaran. Jakarta: Prestasi Pustakaraya.

Nila, K. (2008). Pemahaman Konsep Matematik dalam Pembelajaran Matematika. Prosiding Seminar Nasional Matematika dan Pendidikan Matematika. Jurusan Pendidikan Matematika Fakultas 
Matematika dan Ilmu Pengetahuan Alam Universitas Negeri Yogyakarta. Diambil dari http://eprints.uny.ac.id/6928/

Nurhayati, S. (2012). Peningkatan Hasil Belajar

Matematika Pada Materi Logika

Menggunakan Alat Peraga Magic Box

(PTK Siswa Kelas XI SMK Harapan

Kartasura Tahun Ajaran 2011/2012).

Universitas Muhammadiyah Surakarta.

Diambil

dari

http://eprints.ums.ac.id/20899/.

Purwanto, N. (2012). Prinsip-prinsip dan Teknik

Evaluasi Pengajaran. Bandung: Remaja

Rosdakarya.

Ricardo. (2007). Cakrawala Matematika untuk

SMA dan MA Kelas X. Bandung: Alfabeta

Sabandar, J. (2013). Berpikir Reflektif dalam

Pembelajaran Matematika. Tersedia di

website: http://file. upi.

edu/Direktori/FPMIPA/Jur.__Pend.

_Matematika.

Sugiyono. (2015). Metode Penelitian

Pendidikan. Bandung: Alfabeta.

Sukardi. (2013). Metode Penelitian Pendidikan

Tindakan Kelas Implementasi dan

Pengembangannya. Jakarta: Bumi Aksara.

Sumarmo, U. (2003, Oktober). Daya dan

Disposisi Matematik: Apa, Mengapa dan

Bagaimana Dikembangkan pada Siswa

Sekolah Dasar dan Menengah. Makalah disajikan pada Seminar Sehari di Jurusan Matematika ITB.

Suparno. (2013). Pengaruh Pembelajaran Matematika Menggunakan Model Learning Cycle 7e terhadap Pemahaman Konsep dan Berpikir Kritis Siswa MA Wahid Hasyim Kelas X Yogyakarta. UIN Sunan Kalijaga. Diambil dari http://digilib.uin-suka.ac.id/id/eprint/9104.

Syah, M. 2011. Psikologi Pendidikan. Jakarta: Remaja Rosdakarya.

Trianto. 2007. Model-model Pembelajaran Inovatif Berorientasi Konstruktivistik. Jakarta: Prestasi Pustaka.

Undang-Undang Republik Indonesia. 2008. Undang-Undang No 20 Tahun 2003. Jakarta: Visimedia.
Uno, $\mathrm{H}$ dan Koni, S. 2013. Assessment Pembelajaran. Jakarta: Bumi Aksara.

Wagiman. 2010. Konsep dan Logika. Bandung: Alfabeta.

Wahyuningtyas, D. (2016). Pipa Logika Matematika. Diambil dari https://www.youtube.com/watch? $\mathrm{v}=\mathrm{RxiFz}$ Lzka6U

Wardhani, S. (2008). Analisis SI dan SKL Mata Pelajaran Matematika SMP/MTs untuk Optimalisasi Tujuan Mata Pelajaran Matematika. Yogyakarta: Pusat Pengembangan dan Pemberdayaan Pendidik dan Tenaga Kependidikan Matematika. Diambil dari https://sites.google.com/site/kkgmgmpmat ematika/13-Analisis.

Yulianti, E., Zulkardi, Z., \& Siroj, R. A. (2010). Pengembangan Alat Peraga Menggunakan Rangkaian Listrik Seri-Paralel Untuk Mengajarkan Logika Matematika Di SMK Negeri 2 Palembang. Jurnal Pendidikan Matematika, 4(1), 25-32. 
JURNAL GANTANG. Maret 2018; III(1): 55 - 61

p-ISSN. 2503-0671

e-ISSN. 2548-5547 